\title{
PENGARUH PERLAMBATAN EKONOMI GLOBAL DAN KINERJA KEUANGAN BANK TERHADAP PENGEMBALIAN SAHAM BANK-BANK KOMERSIAL DI BURSA EFEK INDONESIA
}

\author{
Acik Agfiyani* dan Serly* \\ *Jurusan Akuntansi, Fakultas Ekonomi \\ Universitas Internasional Batam \\ *Email: acikagfiyani@yahoo.com; serly@uib.ac.id
}

\begin{abstract}
This study aims to determine the effect of global economic slowdown and bank financial performance on the return of shares of commercial banks on the IDX. The independent variables used are NIM, NPL, CAR, LDR, Indonesian GDP, Chinese GDP, and American GDP.

This study uses a sample of 31 commercial banks listed on the IDX in the period 20132017. The results of the study state that China's GDP and NPL have a positive effect on stock returns. The independent variable of American GDP has a negative effect on stock returns. Whereas NIM, CAR, LDR, and Indonesian GDP are declared not to affect stock returns.
\end{abstract}

Keywords: Stock returns, bank financial performance, GDP

\section{PENDAHULUAN}

Dalam perkembangan ekonomi, pasar saham merupakan hal penting yang memiliki peran sebagai perantara antara peminjam dan pemberi pinjaman. Pasar saham dapat memobilisasi modal jangka panjang kepada perusahaan-perusahaan yang terdaftar dengan menghimpun dana dari investor yang berbeda untuk memasukkan kelebihan dana mereka yang kemudian akan memperluas bisnis perusahaan (Ashaolu \& Ogunmuyiwa, 2011). Pasar saham biasanya memperdagangkan ratusan saham perusahaan yang terdaftar setiap hari. Dalam beberapa tahun terakhir, saham telah menjadi pilihan investasi terbaik untuk para investor mendapatkan keuntungan dimasa mendatang. Tujuan para investor membeli saham adalah mendapat pengembalian saham yang tinggi. Jeyanthi dan William (2010) mendefinisikan pengembalian saham sebagai laba yang didapatkan investor karena kenaikan harga saham. Investor akan mengevaluasi kinerja pasar saham dengan mengamati level dari berbagai indeks pasar gabungan sebelum menginvestasikan dana surplus mereka agar investasi mereka tidak mengalami kerugian. Menurut Zhang (2008), analisis indeks pasar dapat memberikan perkiraan tren pasar masa depan kepada investor.

Krisis ekonomi global merupakan suatu peristiwa ekonomi yang disebabkan oleh guncangan ekonomi seperti masalah ekonomi pasar karena kebangkrutan atau karena keadaan ekonomi yang carut marut dan menyebabkan keruntuhan dalam pasar dunia serta mempengaruhi sektor lainnya di seluruh dunia. Krisis perekonomian yang pernah terjadi di negara Amerika pada tahun 2007 telah mempengaruhi pasar keuangan dunia, pasar saham international, dan pasar luar negeri (Lee, 2012). Dengan terpilihnya Donald Trump sebagai presiden dengan kebijakan anti perdagangan bebas dikhawatirkan akan menyebabkan ekonomi global semakin melambat (Wolfers \& Zitzewitz, 2016).

Kebijakan-kebijakan Donald Trump diperkirakan akan menyebabkan 
pertumbuhan ekonomi Amerika semakin menguat. Tidak menutup kemungkinan investor dalam negeri akan kabur ke Amerika untuk berinvestasi. Bank Indonesia menilai keluarnya dana asing (capital outflow) dari tanah air tidak hanya disebabkan karena kebijakan Donald Trump tetapi juga karena kenaikan suku bunga Fed bank sentral Amerika (Cable News Network Indonesia, 2018). Kenaikan suku bunga Fed menyebabkan dolar terus menguat dimana dapat berpotensi menyebabkan perlambatan ekonomi dan gejolak di pasar saham. Hal ini telah menyebabkan kekhawatiran sendiri bagi kalangan perbankan. Kenaikan suku bunga acuan telah menyebabkan kenaikan suku bunga kredit, meski efeknya bergantung pada struktur pendanaan masing-masing bank. Apabila suku bunga kredit bank naik maka akan menyebabkan semakin kecil permintaan kredit dikarenakan tingginya suku bunga dan secara langsung akan berakibat pada kredit macet (NPL) yang semakin meningkat. Kenaikan suku bunga kredit juga dapat menyebabkan penurunan pada margin bunga bersih atau net interest margin bank tersebut.

Berdasarkan pada latar belakang tersebut maka diperlukan penelitian kembali untuk mengetahui pengaruh perlambatan ekonomi global dan rasiorasio keuangan bank terhadap pengembalian saham yang kemudian dapat menjadi informasi tambahan bagi investor dalam membuat keputusan. Dengan demikian penelitian ini akan mengangkat judul "Pengaruh Perlambatan Ekonomi Global dan Kinerja Keuangan Bank pada Pengembalian Saham Bank-Bank Komersial di Bursa Efek Indonesia”.

\section{KAJIAN LITERATUR DAN PENGEMBANGAN HIPOTESIS}

Beberapa peneliti terdahulu telah melakukan penelitian dengan variabel dependen yang sama yaitu pengembalian saham. Penelitian-penelitian tersebut ada yang berasal dari Indonesia dan luar negeri seperti Taiwan, Amerika, India, Kenya,
Pakistan, Sri Lanka, Inggris Raya, dan Afrika Timur. Penelitian yang dilakukan di Indonesia menggunakan bank yang terdaftar di BEI sebagai sampel.

Dianasari, Medyawati, dan Yunanto (2011) meneliti pengaruh kinerja keuangan bank terhadap pengembalian saham dengan mengambil data sampel dari Bursa Efek Indonesia. Peneliti menggunakan sampel bank sebanyak 31 dengan variabel independen return on equity, capital adequacy ratio, loan to deposit ratio, dan non performing loan.

Reddy (2012) melakukan penelitian tentang pengaruh inflasi dan GDP pada pengembalian saham di India pada tahun 1997 sampai 2009. Dalam penelitian ini, peneliti menggunakan real domestic product, interest rate, dan inflation rate sebagai variabel independen.

Abbas et al. (2015) secara empiris menyelidiki hubungan antara lima variabel independen yaitu inflasi, nilai tukar, GDP, harga emas, dan treasury bills rate dengan variabel dependen pengembalian saham pada Bursa Efek Karachi Index 100 Pakistan. Penelitian ini menggunakan sampel data bulanan yang diambil pada periode Januari 2002 hingga Desember 2012.

Laichena dan Obwogi (2015)
meneliti hubungan makroekonomi terhadap pengembalian saham di pasar saham Afrika Timur menggunakan data panel dari 3 negara yaitu Uganda, Kenya, Tanzania, dan Afrika Timur pada tahun 2005-2014. Peneliti menggunakan suku bunga, inflasi, nilai tukar mata uang, dan GDP sebagai variabel independen.

\section{Pengembalian Saham}

Variabel dependen yang digunakan dalam penelitian ini adalah pengembalian saham. Pengembalian saham adalah perubahan modal atau kekayaan karena investasi. Perubahan bisa terjadi karena arus kas seperti laba, dividen atau bunga, atau karena perubahan negatif atau positif dalam harga saham (Babi, 2015). Sedangkan menurut pendapat Corrado dan 
Jordan (2000) menyatakan bahwa pengembalian saham merupakan keuntungan yang didapat atas kepemilikan saham investor karena investasi yang dilakukan. Keuntungan ini terdiri dari dividen dan capital gain/loss.

\section{Pengaruh GDP terhadap Pengembalian Saham}

Dalam penelitian ini, peneliti menggunakan GDP Indonesia, GDP China, dan GDP Amerika sebagai variabel independen. China dan Amerika merupakan negara dengan perekonomian terbesar sehingga guncangan ekonomi yang terjadi pada kedua negara tersebut akan berpengaruh terhadap negara-negara lainnya termasuk Indonesia. GDP adalah nilai konsumsi, investasi dan ekspor neto. Setiap peningkatan konsumsi, investasi, dan ekspor pasti akan berdampak positif pada penjualan perusahaan. Penjualan yang lebih baik dan tinggi akan menyebabkan profitabilitas meningkat sehingga laba per saham meningkat dan menyebabkan pengembalian saham juga meningkat (Mugambi \& Okech, 2016).

Beberapa studi empiris menemukan bahwa ada hubungan positif antara GDP dan pengembalian saham diantaranya Geske dan Roll (1983), Chen et al. (1986), Sharma (2002), Singh et al. (2011), Reddy (2012), Erdugan (2012), Menike et al. (2015), dan Laichena dan Obwogi (2015). Menike et al. (2015) mengungkapkan bahwa peningkatan arus kas dari operasional perusahaan akan menarik investor untuk berinvestasi dalam pasar modal. Oleh sebab itu, terdapat hubungan positif antara GDP dan pengembalian saham.

Beberapa peneliti juga menemukan tidak adanya pengaruh antara GDP dan pengembalian saham diantaranya Mugambi dan Okech (2016) yang melakukan penelitian tentang pengaruh GDP terhadap pengembalian saham di bank-bank yang terdaftar di Nairobi Securities Exchange (NSE) pada periode tahun 2000-2015. Hasil penelitiannya menyatakan bahwa pengaruh GDP tidak signifikan terhadap pengembalian saham di bank-bank yang terdaftar di NSE. Hal ini bisa disebabkan karena ukuran kecil pasar saham dibandingkan dengan GDP keseluruhan. Hasil dari penelitian ini sesuai dengan hasil penelitian yang dilakukan oleh Osamwonyi dan EvbayiroOsagie (2012), Kirui et al. (2014), Mustapha Wasseja (2015), dan Alqudah et al. (2017).

\section{Pengaruh Net Interest Margin (NIM) terhadap Pengembalian Saham}

Ilham Zaini et al. (2018) menyatakan bahwa NIM berpengaruh positif terhadap pengembalian saham perbankan di BEI. Pernyataan ini terbukti dengan hasil penelitian dari Roswitasari et al. (2017) dan Zulbetti et al. (2015). Rasio NIM yang tinggi menunjukkan pendapatan bunga yang didapat perusahaan tinggi dan menyebabkan keuntungan bank meningkat sehingga pengembalian saham meningkat.

Syauta dan Widjaja (2009) meneliti tentang pengaruh NIM terhadap pengembalian saham pada 26 saham perbankan yang dipilih dari BEI. Hasil penelitiannya menyatakan bahwa NIM tidak berpengaruh terhadap pengembalian saham perbankan. Dapat diartikan bahwa meningkatnya dan menurunnya NIM tidak akan menyebabkan pengembalian saham meningkat atau menurun. Hasil penelitian terbukti dan sesuai dengan penelitian dari Saeedi (2016) yang menyatakan bahwa tidak adanya korelasi antara NIM dan pengembalian saham disebabkan karena pelaku pasar dan investor yang membeli dan menjual saham bank hanya melihat imbalan berupa dividen. Sedangkan Altunbas et al. (2000) berpendapat bahwa besarnya NIM belum dapat menjadi acuan bank memiliki profitabilitas besar karena bank juga harus mengelurkan biaya operasional yang juga besar sehingga menyebabkan tidak ada korelasinya NIM dengan pengembalian saham. 
Pengaruh Loan to Deposit Ratio (LDR) terhadap Pengembalian Saham

Loan to Deposit Ratio adalah instrumen perbankan yang berguna untuk menentukan likuiditas bank dan mempengaruhi profitabilitas bank (Rengasamy, 2014). Nurazi dan Usman (2016) melakukan penelitian tentang pengaruh LDR terhadap pengembalian saham dengan menggunakan sampel 16 bank pada tahun 2002-2011. Hasil penelitiannya menyatakan bahwa pengaruh LDR signifikan positif terhadap pengembalian saham. Pernyataan ini konsisten dengan hasil penelitian dari Roswitasari et al. (2017) yang menjelaskan bahwa semakin tinggi LDR maka semakin meningkatkan keuntungan bank dan meningkatkan pengembalian saham.

Berbeda dengan penelitian yang dilakukan oleh Dianasari et al. (2011) yang melakukan penelitian tentang pengaruh LDR terhadap pengembalian saham dengan menggunakan sampel 31 bank di BEI. Hasil penelitiannya menunjukkan bahwa pengaruh LDR tidak signifikan terhadap pengembalian saham. Hasil dari penelitian ini didukung dengan hasil penelitian dari Renwarin (2017), Iskandar (2017), Tripitoko (2015), dan Zulbetti et al. (2015). Tripitoko (2015) menjelaskan bahwa tidak adanya hubungan antara LDR dan pengembalian saham dikarenakan rasio LDR yang tinggi bukan merupakan faktor pendorong naiknya pengembalian saham. Semakin tinggi likuiditas perusahaan bisa berdampak pada kredit yang disalurkan mengalami kemacetan dalam pengembalian. Tidak adanya hubungan LDR dan pengembalian saham bisa juga disebabkan karena rendahnya permintaan kredit sehingga pendapatan bunga bank kecil. Pendapatan bunga yang kecil belum mampu mempengaruhi pengembalian saham.

\section{Pengaruh Capital Adequacy Ratio terhadap Pengembalian Saham}

Salah satu rasio keuangan internal bank yang menunjukkan kekuatan bank dalam menahan kerugian apabila terjadi krisis adalah rasio capital adequacy ratio. Rasio CAR juga mampu mempengaruhi profitabilitas bank dengan melakukan ekspansi atau perluasan usaha (Sangmi \& Nazir, 2010). Angbazo (1997) menemukan bahwa bank-bank dengan modal baik lebih menguntungkan di Amerika. Karki (2004) mengemukakan bahwa ada hubungan positif antara rasio kecukupan modal dan profitabilitas bank.

Pradhan dan Parajuli (2017) menguji pengaruh kecukupan modal terhadap kinerja bank-bank komersial Nepal. Hasil penelitiannya menyatakan bahwa rasio kecukupan modal (CAR) berkorelasi positif terhadap pengembalian saham. Hasil penelitian ini didukung dengan hasil penelitian dari Berger (1995), Zulbetti et al. (2015), Saeedi (2016), Wakid et al. (2013), dan Mwaurah et al. (2017).

\section{Pengaruh Non Performing Loan (NPL) terhadap Pengembalian Saham}

Risiko kredit merupakan risiko gagal bayar atau ketidaksanggupan obligor untuk memenuhi kewajibannya (Huang, 2005). Risiko gagal bayar di bank berkaitan dengan keinginan yang besar untuk pinjaman, perpanjangan kredit yang berlebihan, dan praktik manajemen kredit yang buruk (Greuning \& Bratanovic, 2009).

Vatansever dan Hepsen (2015) meneliti gubungan antara indikator makroekonomi, faktor tingkat bank, dan rasio kredit bermasalah di Turki. Hasil penelitian menunjukkan hubungan negatif antara NPL dan Bursa Efek Istanbul 100 Index. Hasil penelitian ini sesuai dengan penelitian Kang dan Kang (2009), Mwaurah et al. (2017), Aghababaei et al. (2013), Naser et al. (2011), dan Khan et al. (2018). Kang dan Kang (2009) berpendapat semakin rendah risiko kredit maka arus kas perusahaan akan meningkat dan dapat meningkatkan pengembalian saham. 


\section{Perumusan Hipotesis}

$\mathrm{H}_{1}$ : Ada hubungan positif antara GDP Indonesia terhadap pengembalian saham.

$\mathrm{H}_{2}$ : Ada hubungan positif antara GDP China terhadap pengembalian saham.

$\mathrm{H}_{3}$ : Ada hubungan positif antara GDP Amerika terhadap pengembalian saham.

$\mathrm{H}_{4}$ : Ada hubungan positif antara NIM terhadap pengembalian saham.

$\mathrm{H}_{5}$ : Ada hubungan positif antara CAR terhadap pengembalian saham.

$\mathrm{H}_{6}$ : Ada hubungan negatif antara NPL terhadap pengembalian saham.

$\mathrm{H}_{7}$ : Ada hubungan positif antara LDR terhadap pengembalian saham.

\section{METODOLOGI PENELITIAN}

Sampel data yang akan digunakan dalam penelitian ini diambil dari BEI periode 2013-2017. Dari segi waktu pengambilan data, penelitian ini termasuk penelitian time series, dimana data penelitian diambil berdasarkan rentetan waktu (Indriantoro \& Supomo, 2014). Penelitian ini menggunakan variabel independen GDP Indonesia, GDP China, GDP Amerika, NIM, NPL, LDR, dan CAR dan variabel dependen pengembalian saham.

Pemilihan sampel yang digunakan berdasarkan pada beberapa kriteria sebagai berikut: a. Sampel perusahaan perbankan telah terdaftar di Bursa Efek Indonesia periode tahun 2013 sampai dengan tahun 2017.

b. Sampel perusahaan perbankan memiliki laporan keuangan lengkap yang terdiri dari laporan posisi keuangan, laporan laba rugi, dan komprehensif lainnya.

c. Laporan keuangan perusahaan dengan tahun buku terakhir pada 31 Desember.

d. Perusahaan perbankan yang memiliki tanggal Initial Public Offering (IPO) dari tahun 2012.

\section{Variabel Dependen}

Variabel dependen yang digunakan adalah pengembalian saham. Hasil yang diperoleh dari kegiatan investasi dengan cara menghitung selisih harga saham pada periode tahun berjalan dengan periode sebelumnya dengan mengabaikan deviden disebut pengembalian saham. Berikut rumus untuk mencari pengembalian saham menurut Ross et al. (2002):

Keterangan:

$$
R t=\frac{\mathrm{Pt}-(\mathrm{Pt}-1)}{\mathrm{Pt}-1}
$$

Rt : Pengembalian saham pada periode ke-t

Pt : Harga saham pada periode ke-t

Pt-1 : Harga saham periode sebelumnya

\section{Variabel Independen}

Tabel 1

Variabel independen

\begin{tabular}{|l|l|}
\hline Variabel Independen & \multicolumn{1}{c|}{ Keterangan } \\
\hline Non Performing Loan & Non Performing Loan $=\frac{\text { Jumlah kredit bermasalah }}{\text { Total kredit }}$ \\
\hline Loan to Deposit Ratio & Loan to Deposit Ratio $=\frac{\text { Jumlah kredit }}{\text { Dana pihak ketiga }}$ \\
\hline Capital Adequacy Ratio & CAR $=\frac{\text { Modal }}{\text { ATMR }}$ \\
\hline Net Interest Margin & $\mathrm{NIM}=\frac{\text { Pendapatan bunga }}{\text { Aset produktif }}$ \\
\hline $\begin{array}{l}\text { Growth Domestic Product } \\
\text { (GDP) }\end{array}$ & $\begin{array}{l}\text { Konsumsi swasta }+ \text { pembelian pemerintah }+ \text { investasi }+ \\
\text { ekspor neto }\end{array}$ \\
\hline
\end{tabular}

Sumber: Reddy (2012)

Program Studi Akuntansi, Fakultas Ekonomi, Universitas Internasional Batam | 46 


\section{Analisis Regresi Panel}

Metode regresi pada penelitian ini adalah metode analisis linear berganda (multiple regressions). Analisis statistik deskriptif data dan uji outlier data akan diproses pada SPSS (Statistical Package for the Social Science) versi 22. Selanjutnya akan dilakukan pengujian untuk mendapatkan model terbaik menggunakan perangkat lunak eviews. Terdapat tiga model pengujian diantaranya uji Chow, uji Housman, dan uji Multiple Langrange.

\section{HASIL PENELITIAN}

Data yang digunakan adalah data sekunder yang diambil dari website www.idx.co.id, www.finance.yahoo.com, dan www.tradingeconomic.com dengan objek penelitian berupa laporan keuangan dari perusahaan yang bergerak di sektor perbankan dan terdaftar di Bursa Efek Indonesia dengan periode penelitian dari tahun 2013-2017. Sampel penelitian disajikan pada Tabel 2 di bawah ini:

Tabel 2

Sampel Penelitian

\begin{tabular}{lr}
\hline \multicolumn{1}{c}{ Keterangan } & Jumlah \\
\hline Perusahaan yang terdaftar di BEI 2013-2017 & 555 perusahaan \\
Perusahaan yang bergerak disektor perbankan & 43 perusahaan \\
Perusahaan yang dijadikan sampel & 31 perusahaan \\
Jumlah sampel selama periode 5 tahun & 155 sampel \\
Total sampel outlier & 14 sampel \\
Total sampel setelah outlier & 141 sampel \\
\hline
\end{tabular}

Sumber: Data sekunder diolah (2018).

Data perusahaan yang terdaftar di BEI pada tahun 2013-2017 adalah sebanyak 555 perusahaan. Jumlah perusahaan perbankan yang diteliti adalah sebanyak 43 perusahaan. Perusahaan perbankan yang masuk kriteria sebanyak 31 perusahaan perbankan (155 data). Perusahaan perbankan yang masuk dalam

\section{Statistik Deskriptif}

Tabel 3

Statistik Deskriptif Variabel Penelitian

\begin{tabular}{|c|c|c|c|c|c|}
\hline & $\mathrm{N}$ & Minimum & Maximum & Mean & Std. Deviation \\
\hline Pengembalian Saham & 141 & $-0,4598$ & 0,7919 & 0,03565 & 0,26555 \\
\hline NIM & 141 & 0,0109 & 0,1162 & 0,04820 & 0,01992 \\
\hline CAR & 141 & 0,0802 & 0,4202 & 0,18605 & 0,04599 \\
\hline NPL & 141 & 0,0021 & 0,1582 & 0,02918 & 0,02053 \\
\hline LDR & 141 & 0,5043 & 1,4072 & 0,86017 & 0,12697 \\
\hline GDP Indonesia & 141 & 11,9352 & 13,1332 & 12,1772 & 0,46594 \\
\hline GDP China & 141 & 16,9358 & 17,2186 & 17,0653 & 0,11021 \\
\hline GDP Amerika & 141 & 17,3182 & 17,4195 & 17,3711 & 0,03984 \\
\hline Valid N (listwise) & & & & & \\
\hline
\end{tabular}

Sumber: Data sekunder diolah (2018). kriteria adalah perusahaan yang telah memperjualbelikan sahamnya atau memiliki tanggal Initial Public Offering (IPO) dari tahun 2012. Jumlah perusahaan outlier adalah sebanyak 14 data, sehingga jumlah data yang diteliti adalah sebanyak 141 data. 


\section{Uji Chow}

Uji Chow digunakan untuk memilih metode terbaik antara fixed effect model atau metode OLS tanpa variabel dummy. Apabila nilai signifikansi lebih dari $(0,05)$ maka pooled least square merupakan model terbaik yang selanjutnya akan dipilih untuk analisis data. Apabila nilai

Tabel 4

Hasil Uji Chow pada Model Regresi signifikansi ternyata kurang dari $(0,05)$ maka fixed effect model yang lebih tepat digunakan (Ariefianto, 2012). Tabel 4 Uji Chow menunjukkan nilai probabilitas di atas 0,05 yang artinya bahwa model terbaik bagi analisis regresi adalah pooled least square.

\begin{tabular}{lccc}
\hline Test & Statistic & d.f. & Prob \\
\cline { 1 - 2 } Cross-section F & 1,4016 & $(30,10)$ & 0,1086 \\
\hline
\end{tabular}

Sumber: Data sekunder diolah (2018).

\section{Uji Housman}

Uji Housman digunakan untuk memilih model terbaik antara random effect model atau fixed effect model. Tabel

Tabel 5

Hasil Uji Housman pada Model Regresi
5 Uji Housman menunjukkan nilai probabilitas di atas 0,05 yang artinya bahwa model terbaik bagi analisis regresi adalah random effect model.

\begin{tabular}{lccc}
\hline Test & Chi-Sq. Statistic & Chi-Sq. d.f. & Prob \\
\cline { 1 - 2 } Cross-section random & 5,971860 & 7 & 0,5430 \\
\hline
\end{tabular}

Sumber: Data sekunder diolah (2018).

\section{Uji Multiple Langrange}

Hasil Uji Multiple Langrange merupakan uji yang digunakan untuk memilih model antara random effect model dan pooled least square. Untuk mendapatkan nilai statistik Multiple Langrange, peneliti menggunakan nilai residual yang diambil dari eviews kemudian dilakukan perhitungan dalam microsoft excel. Hasil pengujian menunjukkan bahwa nilai Multiple Langrange lebih besar yaitu 1,878 dari nilai chi square 0,05. Dari hasil pengujian tersebut random effect model yang terpilih sebagai model terbaik.

\section{Uji F}

Berdasarkan tabel 6 nilai probabilitas 0,000 yang berarti bahwa keseluruhan variabel independen secara simultan berpengaruh signifikan terhadap variabel dependen. Sehingga variabelvariabel independen NIM, CAR, NPL, LDR, GDP Indonesia, GDP China, GDP Amerika dalam model penelitian ini dapat digunakan untuk memprediksi pengembalian saham. 
Tabel 6

Hasil Uji F

\begin{tabular}{lccc}
\hline Variabel Dependen & Model Regresi Panel & Probabilitas & Kesimpulan \\
\hline Pengembalian Saham & Random Effect Model & 0,0000 & Signifikan \\
\hline
\end{tabular}

Sumber: Data sekunder diolah (2018)

\section{Uji t}

Tabel 7

Hasil Uji $t$

\begin{tabular}{lcccl}
\hline \multicolumn{1}{c}{ Variabel } & Koefisien & t-statistik & Prob & Kesimpulan \\
\hline (Constant) & 31.59748 & 2.102236 & 0.0374 & \\
NIM & -0.446345 & -0.370980 & 0.7112 & Tidak Signifikan \\
CAR & -0.355526 & -0.666507 & 0.5062 & Tidak Signifikan \\
NPL & -3.959858 & -3.528711 & 0.0006 & Signifikan Negatif \\
LDR & 0.123824 & 0.667362 & 0.5057 & Tidak Signifikan \\
GDP Indonesia & 0.042594 & 0.718352 & 0.4738 & Tidak Signifikan \\
GDP China & 1.974063 & 3.767523 & 0.0002 & Signifikan Positif \\
GDP Amerika & -3.780618 & -2.997558 & 0.0032 & Signifikan Negatif \\
\hline
\end{tabular}

Sumber: Data sekunder diolah (2018).

Persamaan regresi dari model penelitian ini disajikan sebagai berikut: Pengembalian Saham $=31.59748$ 0.446345 NIM -0.355526 CAR $e$

\section{H1: Ada hubungan positif antara GDP Indonesia terhadap pengembalian saham. \\ GDP Indonesia berpengaruh positif} terhadap pengembalian saham bank komersial yang terdaftar di Bursa Efek Indonesia.

GDP Indonesia bernilai signifikansi 0,4738. Nilai ini lebih besar dari 0,05 sehingga dapat disimpulkan bahwa GDP Indonesia tidak mempengaruhi pengembalian saham perbankan yang terdaftar di BEI. Hasil penelitian ini
$3.959858 \mathrm{NPL}+0.123824 \mathrm{LDR}+$

0.042594 GDP Ind + 1.974063 GDP China

3.780618 GDP Amerika + didukung dengan hasil penelitian dari Mugambi dan Okech (2016) Alqudah et al. (2017), Kirui et al. (2014), Mustapha Wasseja (2015), dan Osamwonyi dan Evbayiro-Osagie (2012).

Tidak adanya hubungan antara GDP Indonesia dan pengembalian saham bisa disebabkan karena pendapatan ekonomi Indonesia lebih banyak dari ekspor bukan dari investasi. Sumber pendapatan nasional Indonesia paling banyak diperoleh dari industri makanan, transportasi, pergudangan, dan

Program Studi Akuntansi, Fakultas Ekonomi, Universitas Internasional Batam | 49 
telekomunikasi. Artinya sektor perbankan belum mampu memberikan sumbangan lebih untuk pendapatan nasional indonesia. Mugambi dan Okech (2016) juga mengungkapkan bahwa relatif kecilnya sektor perbankan menyebabkan GDP tidak memiliki korelasi terhadap pengembalian saham di sektor perbankan.

\section{H2: Ada hubungan positif antara GDP China terhadap pengembalian saham.}

GDP China berpengaruh signifikan positif terhadap pengembalian saham bank-bank komersial yang terdaftar di Bursa Efek Indonesia.

GDP China menunjukkan pengaruh positif terhadap pengembalian saham. Hasil penelitian ini konsisten dengan hasil penelitian Geske dan Roll (1983), Chen et al. (1986), Sharma (2002), Singh et al. (2011), Reddy (2012), Erdugan (2012), Erdalinda et al. (2015), Menike et al. (2015), dan Laichena dan Obwogi (2015)

Erdalinda et al. (2015) mengungkapkan bahwa korelasi positif antara GDP China dan pengembalian saham dikarenakan China merupakan mitra dagang terbesar Indonesia. Pertumbuhan dan perlambatan ekonomi yang terjadi di China maka akan berdampak ke Indonesia. Pertumbuhan ekonomi yang lebih baik di China akan memberikan pengaruh positif bagi Indonesia. Risiko NPL dalam perbankan akan kecil karena China mampu membayar hutang-hutangnya. Sehingga arus kas perusahaan perbankan menjadi meningkat dan akan meningkatkan pengembalian saham.

\section{H3: Ada hubungan positif antara GDP Amerika terhadap pengembalian saham. \\ GDP Amerika berpengaruh} signifikan positif terhadap pengembalian saham bank-bank komersial yang terdaftar di Bursa Efek Indonesia.

GDP Amerika menunjukkan pengaruh negatif terhadap pengembalian saham dan konsisten dengan hasil penelitian yang dilakukan oleh Ritter (2005). Artinya apabila GDP Amerika meningkat justru akan mengurangi pengembalian saham. Hal ini bisa disebabkan karena apabila ekonomi Amerika menguat, maka investor akan kabur ke negara dengan penghasilan ekonomi terbesar tersebut. Investor akan mencabut dana yang tertanam sehingga menyebabkan arus kas perusahaan menjadi tidak baik. Bank akan menurunkan suku bunga demi mendapatkan dana kembali dan akan menyebabkan pengembalian saham menurun.

\section{H4: Ada hubungan positif antara NIM terhadap pengembalian saham. \\ NIM berpengaruh signifikan positif} terhadap pengembalian saham bank-bank komersial yang terdaftar di Bursa Efek Indonesia.

Net Interest Margin (NIM) atau rasio bunga kredit yang disalurkan dinyatakan tidak mempengaruhi pengembalian saham. Hasil dari penelitian ini sama dengan hasil penelitian yang dilakukan oleh Syauta dan Widjaja (2009), Erdalinda et al. (2015), dan Saeedi (2016). NIM merupakan keuntungan bank dalam negeri yang tercermin dari margin bunga bersih. Semakin tinggi NIM berarti semakin tinggi juga bunga kredit yang diberikan oleh bank sehingga menyebabkan keuntungan bank menjadi meningkat. Apabila keuntungan bank meningkat maka pengembalian saham juga meningkat. Penelitian ini dinyatakan NIM tidak signifikan terhadap pengembalian saham. Hal ini dapat disebabkan oleh rasio NIM yang besar belum tentu menunjukkan bahwa bank tersebut memiliki profitabilitas yang besar karena biaya operasional yang harus dikeluarkan bank pun juga besar (Altunbas et al., 2000). Sedangkan menurut Saeedi (2016) menyatakan bahwa tidak adanya korelasi antara NIM dan pengembalian saham disebabkan karena pelaku pasar dan investor yang membeli dan menjual saham 
bank hanya melihat imbalan berupa dividen.

\section{H5: Ada hubungan positif antara CAR terhadap pengembalian saham.}

CAR berpengaruh signifikan positif terhadap pengembalian saham bank-bank komersial yang terdaftar di Bursa Efek Indonesia.

Capital Adequacy Ratio (CAR) atau rasio kecukupan modal menunjukkan nilai 0,5062 . Nilai ini lebih besar dari 0,05 sehingga dapat dinyatakan bahwa rasio CAR tidak mempengaruhi pengembalian saham. Pernyataan ini didukung dengan hasil penelitian dari Dianasari et al. (2011), Nurazi dan Usman (2016), dan Tripitoko (2015). Dapat diartikan bahwa naik turunnya nilai CAR tidak akan membuat pengembalian saham juga meningkat atau menurun. Hasil penelitian ini menyatakan bahwa informasi rasio CAR belum mampu memberikan gambaran bagi investor dalam memperkirakan pengembalian saham yang akan diperoleh. Rasio CAR belum cukup baik dalam menggambarkan pengembalian saham yang akan didapat investor akan sepadan dengan risiko yang akan ditanggungnya. Sehingga dengan naiknya CAR bisa saja membuat pengembalian saham menurun.

Semakin besar modal yang dimiliki bank, maka akan semakin banyak kesempatan bank dalam menyalurkan kredit untuk menghasilkan pendapatan bank sehingga akan berpengaruh terhadap pengembalian saham yang juga meningkat. CAR dinyatakan tidak berpengaruh terhadap pengembalian saham dikarenakan kemungkinan bank lebih banyak menggunakan modalnya bukan untuk aset produktif yang bisa menghasilkan pendapatan bagi bank, tetapi untuk keperluan aset lainnya seperti aset tetap yang tidak bisa menimbulkan pendapatan bagi bank (Zulbetti et al., 2015). Sedangkan Tripitoko (2015) berpendapat bahwa tidak adanya pengaruh antara CAR dan pengembalian saham bisa disebabkan karena modal bank terdiri modal pelengkap dan modal inti. Modal pelengkap berasal dari modal pinjaman dan pinjaman subordinasi. Karena modal bank didapat dari pinjaman, maka bank harus memiliki kemampuan dalam membayar hutang-hutangnya.

\section{H6: Ada hubungan negatif antara NPL terhadap pengembalian saham. \\ NPL berpengaruh signifikan negatif} terhadap pengembalian saham bank-bank komersial di Bursa Efek Indonesia.

Rasio risiko kredit menunjukkan nilai $\mathrm{t}$ sebesar 0,0006 sehingga dapat disimpulkan bahwa rasio NPL berpengaruh negatif terhadap pengembalian saham perbankan di BEI. Hasil penelitian ini didukung dengan hasil penelitian dari Vatansever dan Hepsen (2015), Mwaurah et al. (2017), Naser et al. (2011), Aghababaei et al. (2013), Kang dan Kang (2009), dan Khan et al. (2018). Kang dan Kang (2009) berpendapat semakin kecil risiko kredit maka arus kas perusahaan semakin lebih baik.

\section{H7: Ada hubungan positif antara LDR terhadap pengembalian saham.}

LDR berpengaruh signifikan positif terhadap pengembalian saham bank-bank komersial yang terdaftar di Bursa Efek Indonesia.

Pada pengujian LDR menunjukkan nilai signifikansi 0,5057 . Nilai ini lebih besar dari nilai signifikansi 0,05 . Sehingga dapat disimpulkan bahwa rasio LDR tidak mempengaruhi pengembalian saham perbankan yang terdaftar di BEI. Hasil penelitian ini didukung dengan hasil penelitian dari Dianasari et al. (2011), Erdalinda et al. (2015), Renwarin (2017), Tripitoko (2015), Zulbetti et al. (2015), dan Iskandar (2017) yang menyatakan bahwa rasio LDR tidak signifikan terhadap pengembalian saham.

Tripitoko (2015) menjelaskan bahwa tidak adanya hubungan antara LDR dan pengembalian saham dikarenakan rasio LDR yang tinggi bukan merupakan 
faktor pendorong naiknya pengembalian saham. Semakin tinggi likuiditas perusahaan bisa berdampak pada kredit yang disalurkan mengalami kemacetan dalam pengembalian. Tidak adanya hubungan LDR dan pengembalian saham bisa juga disebabkan karena rendahnya permintaan kredit sehingga pendapatan bunga bank kecil. Pendapatan bunga yang kecil belum mampu mempengaruhi pengembalian saham.

\section{Goodness of Fit Model Regresi}

Tabel 8

Hasil Uji Koefisien Determinasi

\begin{tabular}{ccc}
\hline Variabel Dependen & $\begin{array}{c}\text { Adjusted } \mathbf{R} \\
\text { Square }\end{array}$ & Std. Error of The Estimate \\
\hline Pengembalian Saham & 0,167022 & 0,2333163 \\
\hline
\end{tabular}

Sumber: Data sekunder diolah (2018).

Nilai adjusted $R$ square dalam tabel menunjukkan angka 0,167022. Nilai ini menyatakan bahwa dari semua variabel independen yang digunakan dalam penelitian ini mampu menjelaskan variabel dependen sebesar $16,72 \%$. Sisanya yaitu $83,28 \%$ dijelaskan oleh variabel independen lain yang tidak ada dalam model regresi penelitian ini.

\section{KESIMPULAN}

Berdasarkan permasalahan dari penelitian mengenai pengaruh NIM, CAR, NPL, LDR, GDP Indonesia, GDP China, dan GDP Amerika terhadap pengembalian saham perbankan di Bursa Efek Indonesia, dari hasil pembahasan peneliti dapat menyimpulkan hasil pengujian masingmasing variabel independen sebagai berikut:

1. Net Interest Margin (NIM) atau rasio bunga kredit yang disalurkan dinyatakan tidak signifikan terhadap pengembalian saham perbankan di BEI. Hasil dari penelitian ini konsisten dengan hasil penelitian yang dilakukan oleh Syauta dan Widjaja (2009), Erdalinda et al. (2015), dan Saeedi (2016). Hal ini dapat disebabkan oleh NIM yang besar belum dapat menjadi acuan bank memiliki profitabilitas yang besar karena biaya operasional yang juga harus dikeluarkan bank juga besar (Altunbas et al., 2000). Sedangkan menurut Saeedi (2016) menyatakan bahwa tidak adanya korelasi antara NIM dan pengembalian saham disebabkan karena pelaku pasar dan investor yang membeli dan menjual saham bank hanya melihat imbalan berupa dividen.

2. Capital Adequacy Ratio (CAR) atau rasio kecukupan modal dinyatakan tidak signifikan terhadap pengembalian saham perbankan di BEI. Hasil dari penelitian ini konsisten dengan hasil penelitian yang dilakukan oleh Dianasari et al. (2011), Nurazi dan Usman (2016), dan Tripitoko (2015). Tripitoko (2015) berpendapat bahwa tidak adanya pengaruh antara CAR dan pengembalian saham bisa disebabkan karena modal bank terdiri dari modal pelengkap dan modal inti. Modal pelengkap berasal dari modal pinjaman dan pinjaman subordinasi. Dikarenakan modal bank didapat dari pinjaman, maka bank harus memiliki kemampuan dalam membayar hutang-hutangnya. Sedangkan Zulbetti et al. (2015) menjelaskan bahwa modal yang besar tidak hanya digunakan untuk pendanaan aset produktif yang bisa menghasilkan pendapatan tetapi juga untuk aset tetap dan investasi lainnya. Artinya apabila modal lebih banyak tertanam dalam aset tetap tidak akan mempengaruhi pengembalian saham.

3. Non Performing Loan (NPL) atau rasio kredit bermasalah dinyatakan signifikan negatif terhadap pengembalian saham 
perbankan di BEI. Hasil dari penelitian ini sesuai dengan penelitian yang dilakukan oleh Vatansever dan Hepsen (2015), Mwaurah et al. (2017), Rawhi Hashem et al. (2017), Roswitasari et al. (2017), Naser et al. (2011), Aghababaei et al. (2013), Kang dan Kang (2009), dan Khan et al. (2018). Kang dan Kang (2009) berpendapat bahwa risiko kredit rendah akan menyebabkan pengembalian saham lebih tinggi. Semakin kecil risiko kredit maka arus kas perusahaan semakin lebih baik dikarenakan kelancaran peminjam dalam membayar hutang-hutangnya. Semakin baik arus kas perusahaan maka perusahaan dapat memiliki kesempatan lebih banyak untuk menyalurkan kredit sehingga akan meningkatkan pendapatan bunga dan akan meningkatkan pengembalian saham dikarenakan profitabilitas bank meningkat.

4. Loan to Deposit Ratio (LDR) dinyatakan tidak signifikan terhadap pengembalian saham perbankan di BEI. Hasil dari penelitian ini sesuai dengan hasil penelitian yang dilakukan oleh Dianasari et al. (2011), Erdalinda et al. (2015), Renwarin (2017), Tripitoko (2015), Zulbetti et al. (2015), dan Iskandar (2017). Tripitoko (2015) menjelaskan bahwa tidak adanya hubungan antara LDR dan pengembalian saham dikarenakan rasio LDR yang tinggi bukan merupakan faktor pendorong naiknya pengembalian saham. Semakin tinggi likuiditas perusahaan bisa berdampak pada kredit yang disalurkan mengalami kemacetan dalam pengembalian. Tidak adanya hubungan LDR dan pengembalian saham juga bisa disebabkan karena rendahnya permintaan kredit sehingga pendapatan bunga bank kecil. Pendapatan bunga yang kecil belum mampu mempengaruhi pengembalian saham.

5. GDP Indonesia dinyatakan tidak signifikan terhadap pengembalian saham perbankan di BEI. Hasil dari penelitian ini sesuai dengan hasil penelitian yang diteliti oleh Mugambi dan Okech (2016), Alqudah et al. (2017), Kirui et al. (2014), Mustapha Wasseja (2015), dan Osamwonyi dan Evbayiro-Osagie (2012). Mugambi dan Okech (2016) mengungkapkan bahwa relatif kecilnya sektor perbankan menyebabkan GDP Indonesia tidak memiliki korelasi terhadap pengembalian saham di sektor perbankan.

6. GDP China dinyatakan berpengaruh positif terhadap pengembalian saham perbankan di BEI. Hasil penelitian ini konsisten dengan hasil penelitian Geske dan Roll (1983), Chen et al. (1986), Sharma (2002), Singh et al. (2011), Reddy (2012), Erdugan (2012), Erdalinda et al. (2015), Menike et al. (2015), dan Laichena dan Obwogi (2015). Erdalinda et al. (2015) mengungkapkan bahwa korelasi positif antara GDP indonesia dan pengembalian saham dikarenakan China merupakan mitra dagang terbesar Indonesia. Pertumbuhan dan perlambatan ekonomi yang terjadi di China maka akan berdampak ke Indonesia. Pertumbuhan ekonomi yang lebih baik di China akan memberikan pengaruh positif bagi Indonesia. Risiko NPL dalam perbankan akan kecil karena China mampu membayar hutang-hutangnya. Sehingga arus kas perusahaan perbankan menjadi meningkat dan akan meningkatkan pengembalian saham.

7. GDP Amerika dinyatakan berpengaruh negatif terhadap pengembalian saham perbankan di BEI dan konsisten dengan hasil penelitian yang dilakukan oleh Ritter (2005). Hal ini bisa dipicu karena apabila ekonomi Amerika menguat, maka investor akan kabur ke negara tersebut dan mencabut dana dalam negeri. Hal ini dapat menyebabkan arus kas perusahaan menjadi tidak baik 
sehingga suku bunga menurun dan pengembalian saham menurun.

\section{Keterbatasan}

Berikut beberapa keterbatasan dalam penelitian sebagai berikut:

1. Dalam melakukan pengujian uji Multiple Langrange, peneliti mengambil nilai residu dalam eviews kemudian dilakukan perhitungan dalam microsoft excel. Hal ini menyebabkan nilai probabilitas tidak muncul secara otomatis dan memakan waktu yang tidak singkat.

2. Hasil penelitian variabel independen GDP Amerika hanya didukung oleh Ritter (2005).

\section{Rekomendasi}

Untuk keperluan penelitian selanjutnya, diharapkan dapat mengatasi keterbatasan dalam penelitian ini sebagai berikut:

1. Diharapkan pada penelitian selanjutnya, peneliti bisa melakukan pengujian uji Multiple Langrange dengan aplikasi statistika sehingga hasil akan keluar secara otomatis dan tidak memakan waktu yang cukup lama.

2. Diharapkan pada penelitian selanjutnya, peneliti dapat lebih memperbanyak jurnal pendukung untuk lebih memperkuat hasil yang telah diteliti peneliti sebelumnya.

\section{DAFTAR PUSTAKA}

Abbas, S., Tahir, S. H., \& Raza, S. (2015). Impact of Macroeconomic Variables on Stock Markets: Evidence from Emerging Markets. International Journal of Economics and Finance, $8(1)$, 195. https://doi.org/10.5539/ijef.v8n1p195

Aghababaei, H. ., Ataei, S., \& Azizkhani, H. (2013). Effects of Credit Risk Indicators on Shareholders' Market Value of Commercial Banks in IRAN. International Research Journal of Applied and Basic Sciences, 6, 11431149.

Alqudah, L. A., Akram, L., \& Al -Qudah,
M. (2017). The Factors that affect shares' Return in Amman Stock Market INTERDISCIPLINARY JOURNAL OF CONTEMPORARY RESEARCH IN BUSINESS The Factors that affect shares' Return in Amman Stock Market. Retrieved from https://www.researchgate.net/publicat ion/321885721

Altunbas, Y., Liu, M., Molyneux, P., \& Seth, R. (2000). Efficiency and Risk in Japanese Banking. Journal of Banking and Finance, 24(10), 16051628.

Angbazo, L. (1997). Journalof BANKING \& FINANCE Commercial bank net interest margins, default risk, interestrate risk, and off-balance sheet banking. ELSEVIER Journal of Banking \& Finance Journal of Banking \& Finance, 21(21), 55-87. https://doi.org/10.1016/S03784266(96)00025-8

Ariefianto, M. D. (2012). Ekonometrika Esensi dan Aplikasi dengan Menggunakan EViews. Jakarta: PT. Gelora Aksara Pratama.

Ashaolu, T. O., \& Ogunmuyiwa, M. S. (2011). An Econometric Analysis of the Impact of Macro Economic Variables on Stock market movement in Nigeria. Journal of Business Management, 3(1), 72-78.

Babi, M. A. (2015). The effects of financial risks on the relationship between earnings and stock returns. International Journal of Organization Leadership, 4, 154-169.

Berger, A. N. (1995). The Profit-Structure Relationship in Banking-Tests of Market-Power and Efficientstructure Hypotheses. Journal of Money, Credit and Banking, 27(2), 404-431.

CNN Indonesia. (2018). BI Sebut Kebijakan Ekonomi AS Bikin Dana Asing "Kabur." https://www.cnnindonesia.com/ekono mi/20180830135132-532-326155/biSebut-Kebijakan-Ekonomi-as-BikinDana-Asing-Kabur. 
Corrado, \& Jordan. (2000). Fundamentals of Investment Analysis (Fourth). singapore: Mc Graw Hill.

Dianasari, N., Medyawati, H., \& Student, M. Y. (n.d.). Financial Ratios, Return Stock and Financial Report: Do They Always Affect Each Other?

Erdugan, R. (2012). The Effect of Economic Factors on the Performance of the Australian Stock Market A thesis submitted in fulfillment of the by Riza Erdugan School of Accounting and Finance. Victoria University, (February).

Greuning, H. van, \& Bratanovic, S. B. (2009). Analyzing Banking Risk"A Framework for Assessing Corporate Governance and Risk Management" (third). https://doi.org/10.1596/978-08213-7728-4

Huang, D. (2005). The Predictive Power of Capital Adequacy Ratios on Bank Risk. Journal of Contemporary Accounting, 6(1), 1-22.

Ilham Zaini, V., Sadalia, I., \& Amalia Fachrudin, K. (2018). The Effect Of External And Internal Factors On Stock Return With Price To Book Value As Moderation Variables In Banking Companies In Indonesia Stock Exchange. INTERNATIONAL JOURNAL OF SCIENTIFIC \& TECHNOLOGY RESEARCH, 7(9). Retrieved from www.ijstr.org

Indriantoro, \& Supomo. (2014). Metodologi Penelitian Bisnis untuk Akuntansi \& Manajemen. Yogyakarta: BPFE.

Iskandar, Y. (2017). TO OPERATING INCOME , AND LOAN TO DEPOSIT RATIO, (2009), 25-30.

Jeyanthi, B. J. Q., \& William SJ, M. A. (2010). Bank Stock Performance since the 2000s. Curpe, 3(1).

Kang, C., \& Kang, H. . (2009). The Effect of Credit Risk on Stock Returns. Journal of Economic Research, 14, 49-67.

Karki, L. (2004). Liquidity Ratio with Loan and Advances. Journal of
Nepalese Business Studies, 2(4), 3245.

Khan, M. N., Alam, A., Arshad, S., Shah, A., Ilyas, M., \& Ali, M. D. (2018). Credit Risk, Liquidity Risk and Stock Return , ( Evidence from Pakistan Stock Exchange ), 8(4), 95-102.

Kirui, E., Wawire, N. H. W., \& Onono, P. O. (2014). Macroeconomic Variables, Volatility and Stock Market Returns: A Case of Nairobi Securities Exchange, Kenya. International Journal of Economics and Finance, 6(8), 214-228. https://doi.org/10.5539/ijef.v6n8p214

Laichena, kaunyangi eliud, \& Obwogi, tabitha nasieku. (2015). EFFECTS OF MACROECONOMIC VARIABLES ON STOCK RETURNS IN THE EAST AFRICAN COMMUNITY STOCK EXCHANGE MARKET Kaunyangi Eliud Laichena * 1 Tabitha Nasieku Obwogi 2 1., 3(10), 305-320.

Lee, H.-Y. (2012). Contagion in International Stock Markets during the Sub Prime Mortgage Crisis. International Journal of Economics and Financial Issues, 2(1), 41-53. Retrieved from www.econjournals.com

M. C. S. Menike, L. (2015). Macroeconomic and Firm Specific Determinants of Stock Returns: A Comparative Analysis of Stock Markets in Sri Lanka and in the United Kingdom. Journal of Finance and Accounting. https://doi.org/10.11648/j.jfa.2015030 4.14

Mugambi, M., \& Okech, T. C. (2016). International Journal of Economics, Commerce and Management EFFECT OF MACROECONOMIC VARIABLES ON STOCK RETURNS OF LISTED COMMERCIAL BANKS IN KENYA. Retrieved from http://ijecm.co.uk/

Mustapha Wasseja, M. (2015). Investigation of the Granger Causal 
Relationship

Between

Macroeconomic Variables and Stock

Prices in Kenya. International Journal of Business and Economics Research, 4(3), 98. https://doi.org/10.11648/j.ijber.20150 403.13

Mwaurah, I., Muturi, W., \& Waititu, A. (2017). The Influence of Financial Risk on Stock Returns. International Journal of Scientific and Research Publications, 7(5), 418. Retrieved from www.ijsrp.org

Naser, S., Mohammad, E., Mohammad, R. ., \& Akbar, A. . (2011). Designing and Identifying the model to Investigate the Effect of Credit and Exchange Risk on Stock Returns of Banks (GARCH Approach). Australian Journal of Basic and Applied Sciences, 5(11), 1519-1532.

Nurazi, R., \& Usman, B. (2016). Bank Stock Returns in Responding the Contribution of Fundamental and Macroeconomic Effects. Jejak, 9(1), 129-144.

https://doi.org/10.15294/jejak.v9i1.71 91

Osamwonyi, I. O., \& Evbayiro-Osagie, E. I. (2012). The Relationship between Macroeconomic Variables and Stock Market Index in Nigeria. Journal of Economics, 3(1), 55-63. https://doi.org/10.1080/09765239.201 2.11884953

Pradhan, R. S. (2017). Impact of Capital Adequacy and Cost Income Ratio on Performance of Nepalese Commercial Banks Pratikshya Parajuli. International Journal of Management Research (Vol. 8).

Rawhi Hashem, F. N., Alduneibat, K. A. A., \& Fayad altawalbeh, M. abdallah. (2017). The Impacts of NonPerforming Loans upon the Prices of Stocks in Jordanian Commercial Banks. Accounting and Finance Research, 6(1), 139. https://doi.org/10.5430/afr.v6n1p139 Reddy, D. V. L. (2012). IMPACT OF
INFLATION AND GDP ON STOCK MARKET RETURNS IN INDIA. International Journal of Advanced Research in Management and Social Sciences. Retrieved from www.garph.co.uk

Rengasamy, D. (2014). Impact of loan deposit ratio (LDR) on profitability: Panel evidence from commercial banks in Malaysia. Proceedings of the Third International Conference on Global Business, Economics, Finance and Social Sciences (GB14Mumbai Conference) Mumbai, India, 978-19415(19-21 December), : MF498. https://doi.org/10.1002/chem.2007003 99

Renwarin, J. M. J. (n.d.). THE INFLUENCE OF FINANCIAL PERFORMANCE AND FINANCIAL DISTRESS ON STOCK RETURN. International Journal of Technical Research and Applications (Vol. 5). Retrieved from www.ijtra.com

Ross, S. ., Weterfield, R. ., \& Jaffe. (2002). Corporate Finance. USA: MC GrowHill, Inc.

Roswitasari, L. D., Achsani, N. A., \& Andati, T. (2017). Banking Subsector: Performance Ratio Influence to Bank' s Stock Prices during the $\mathrm{P}$ eriod 2010 - 2014. International Journal of Science and Research (IJSR), 6(2), 627-633. https://doi.org/10.21275/ART201760 2

Saeedi, D. A. (2016). Investigating the relationship between stock returns and situation of risk management at accepted banks from the perspective of shareholders in stock exchange of Iran, 2719-2734.

Sangmi, M.-D., \& Nazir, T. (2010). Analyzing Financial Performance of Commercial Banks in India: Application of CAMEL Model. Soc. Sci, 4(1), 40-55.

Singh, T., Mehta, S., \& Varsha, M. S. (2011). Macroeconomic factors and stock returns: Evidence from Taiwan. 
Journal of Economics and International Finance, 2(4), 217-227. Retrieved from http://www.academicjournals.org/JEI $\mathrm{F}$

Syauta, R. C., \& Widjaja, I. (2009). Analisis pengaruh rasio roa, $\mathrm{ddr}$, nim dan npl terhadap, 1(6), 351-367.

Tripitoko, gigih bagus. (2015). Pengaruh Loan To Deposit Ratio, Capital Adequacy ratio, Operating Cash Flow dan Return On Equaty terhadap Return Saham ( Studi Pada Perusahaan Perbankan yang Terdaftar di Bursa Efek Indonesia Tahun Abstrak. Akuntansi, 2(3), 3192-3198.

Vatansever, M., \& Hepsen, A. (2015). Determining Impacts on NonPerforming Loan Ratio in Turkey. Journal of Applied FInance \& Banking, 5(4), 1-11.

Wakid, K., Arab, N., Madiha, K., Waseem,
K., Qaiser, K., \& Shabeer, A. (2013). The Impact of capital Structure and Financial Performance on Stock Returns ," A Case of Pakistan Textile Industry". Middle East Journal of Scientic Research 16(2), 289-295.

Wolfers, J., \& Zitzewitz, E. (n.d.). What do financial markets think of the 2016 election? *. Retrieved from www.nber.org/ jwolfershttp://www.d artmouth.edu/ ericz/

Zhang, G. (n.d.). Informational Efficiency of Credit Default Swap and Stock markets: The impact of Adverse Credit Events. Retrieved from http://ssrn.com/abstract=1497537Elec troniccopyavailableat:http://ssrn.com/ abstract $=1497537$

Zulbetti, R., AH Prihartono, K., \& Perwito. (2015). Financial Performance, Macroeconomic Factors and Stock Return, 93-99. 